\title{
Interaction of long-chain non-coding RNAs and important signaling pathways on human cancers (Review)
}

\author{
WEI SUN ${ }^{1,2 *}$, YING SHI ${ }^{3 *}$, ZHIFEI WANG ${ }^{2}$, JIYE ZHANG ${ }^{2,4}$, HANHUI CAI $^{2,4}$, \\ JUNGANG ZHANG $^{2}$ and DONGSHENG HUANG ${ }^{2}$
}

\begin{abstract}
${ }^{1}$ Department of Postgraduates, Bengbu Medical College, Bengbu, Anhui 233000; ${ }^{2}$ Department of Hepatobiliary and Pancreatic Surgery and Minimally Invasive Surgery, Zhejiang Provincial People's Hospital, People's Hospital of Hangzhou Medical College; ${ }^{3}$ Department of Obstetrics, Zhejiang Provincial People's Hospital, People's Hospital of Hangzhou Medical College; ${ }^{4}$ Department of Postgraduates, Zhejiang Chinese Medical University, Hangzhou, Zhejiang 310014, P.R. China
\end{abstract}

Received June 8, 2018; Accepted August 24, 2018

DOI: $10.3892 /$ ijo.2018.4575

\begin{abstract}
Long non-coding RNAs (lncRNAs) usually refer to non-coding RNA transcripts $>200$ nucleotides in length. In terms of the full genomic transcript, the proportion of lncRNAs far exceeds that of coding RNA. Initially, lncRNAs were considered to be the transcriptional noise of genes, but it has since been demonstrated that lncRNAs serve an important role in the regulation of cellular activities through interaction with DNA, RNA and protein. Numerous studies have demonstrated that various intricate signaling pathways are closely related to lncRNAs. Here, we focus on a large number of studies regarding the interaction of lncRNAs with important signaling pathways. It is comprehensively illustrated that IncRNAs regulate key metabolic components and regulatory factors of signaling pathways to affect the biological activities of tumor cells. Evidence suggests that the abnormal expression or mutation of lncRNAs in human tumor cells, and their interaction with signaling pathways, may provide a basis and potential target for the diagnosis and treatment of human cancers.
\end{abstract}

\section{Contents}

1. Introduction

2. IncRNA and the p53 signaling pathway

Correspondence to: Dr Jungang Zhang or Professor Dongsheng Huang, Department of Hepatobiliary and Pancreatic Surgery and Minimally Invasive Surgery, Zhejiang Provincial People's Hospital, People's Hospital of Hangzhou Medical College, 158 Shangtang Road, Hangzhou, Zhejiang 310014, P.R. China

E-mail: zjg2sy1@163.com

E-mail: huangdszj@163.com

*Contributed equally

Key words: long-chain non-coding RNA, signaling pathway, cancers, molecular mechanism, regulation
3. IncRNA and the NF- $\mathrm{NB}$ signaling pathway

4. IncRNA and the Wnt signaling pathway

5. IncRNA and the Notch signaling pathway

6. IncRNA and the PI3K/AKT signaling pathway

7. IncRNA and the MAPK signaling pathway

8. Discussion

\section{Introduction}

The human genome project has demonstrated that $<2 \%$ nucleic acid sequences are protein-coding. In 2002, Okazaki et al (1) first identified a class of longer transcripts by sequencing a mouse cDNA library, and termed them long non-coding RNAs (1ncRNAs). Due to limitations in our understanding of gene regulation and expression, these non-coding RNAs were considered to be transcriptional noise until HOX transcript antisense RNA (HOTAIR) was identified. HOTAIR is a lncRNA located on the antisense strand of the HOXC gene cluster, which regulates the expression of the HOXD gene and the occurrence of H3K4me2 methylation modifications in certain gene regions, and silences expression at this site $(2,3)$. Although lncRNAs do not encode proteins, they participate in important cellular physiological processes. Numerous studies have reported that lncRNAs are abnormally expressed in various types of tumor, and affect the occurrence and development of tumors through different signaling pathways. IncRNAs are generally defined as long-stranded RNAs with $>200$ nucleotides, but this is not absolute. For example, BC1 and snaR are $<200$ nucleotides in length (4). IncRNAs may also be classified according to location, object of action and functional mechanism (5). The progress in IncRNA research is associated with the progress in research technology. It is worth mentioning that RNA-sequencing technology, proposed by the Snyder team at Yale University, has low background noise and is able to detect single-base differences between similar genes or different transcripts caused by variable cleavage in the gene family, as well as low abundance transcripts (6). At present, next-generation sequencing technologies have provided the largest experimental evidence on lncRNA, with the 
advantages of high flux, short duration, high accuracy and abundant information.

IncRNAs participate in the regulation of various biological activities, including genomic imprinting, $\mathrm{X}$-chromosome inactivation, chromosome modification and telomere biology. They are also associated with the occurrence and development of various human diseases, particularly with the occurrence and development of malignant tumors. Their long ribbon-like molecular structure interacts with multiple types of molecules, thus affecting cell biological activities. Signaling pathways participate in the transduction of cell signals through a series of enzymatic reactions, which are regulated by various types of molecules. lncRNA is an important regulator of signaling pathways, and regulates gene expression at a transcriptional, post-transcriptional and epigenetic level. This review focused on the function of lncRNA in several classical signaling pathways.

\section{IncRNA and the p53 signaling pathway}

The p53 gene was first reported in 1979 by Lane and Crawford (7), and $>50 \%$ cancer types have been found to be related to mutations of the p53 gene. A tight and precise regulatory system regulates the activities of $\mathrm{p} 53$-associated signaling pathways to prevent abnormal changes in p53 levels from harming cells. IncRNA has gained increasing attention as an important regulator of $\mathrm{p} 53$ signaling.

The damage induced noncoding (IncRNA-DINO) is a DNA damage-activated transcriptional lncRNA involved in the lncRNA-directed biological DNA damage response. Numerous abnormal changes in the p53 pathway may increase the probability of tumorigenesis. DINO interacts with the p53 protein to promote its stability, which causes protein accumulation, activation of $\mathrm{p} 53$ target proteins and regulates a p53 auto-enhancement loop (Fig. 1). DINO is involved in p53-dependent gene expression, cell cycle arrest and apoptosis. In the absence of DNA damage, artificially upregulating DINO expression can effectively activate the DNA damage response pathway and cell cycle arrest. However, when artificially inhibiting the expression of DINO, the response of cells to p53 signaling is weakened. In mice, inactivation of the DINO gene or the promoter blocks the p53 pathway and improves acute radiation syndrome in vivo (8). Thus, DNA damage-induced lncRNAs form a feedback loop with homologous transcription factors to enhance cell signaling networks. A genome-wide transcriptome analysis of human diploid fibroblasts revealed that IncRNA metastasis associated lung adenocarcinoma transcript 1 (MALAT1) is involved in regulating the expression of cell cycle-associated genes, and is required for G1/S and mitotic progression. Low expression of MALAT1 leads to the activation of p53 and its target genes, and cell cycle defects observed in MALAT1-depleted cells are sensitive to p53 expression levels, indicating that p53 is a key downstream mediator of MALAT1. Furthermore, reduced expression of an oncogenic transcription factor, B-MYB, which is involved in G2/M progression, is expressed in MALAT1-depleted cells due to altered binding of splicing factors on B-MYB pre-mRNA and aberrant alternative splicing (9). These findings reveal the mechanism by which IncRNA regulates cell proliferation.

lncRNAs also regulate p53, subsequently affecting cell cycle progression, for example via IncRNA regulator of repro- gramming (lncRNA-ROR). Unlike MDM2, which leads to p53 degradation through the ubiquitin-proteasome pathway, it directly inhibits p53 through interactions with heterogeneous nuclear ribonucleoprotein I (hnRNP I) at the translational level. ROR carries an hnRNP I binding domain that acts on the 5'-untranslated region of p53 mRNA to suppress the translation of p53, thereby inhibiting p53-mediated cell cycle arrest and apoptosis. The induction of $\mathrm{p} 53$ following treatment with doxorubicin increases ROR expression levels, and the ectopic expression of p53 induces ROR production, resulting in a ROR-p53 auto-regulatory feedback loop (10). Similarly to mRNA, the major transcriptional processes of IncRNA are regulated by various factors, including $\mathrm{p} 53, \mathrm{NF}-\kappa \mathrm{B}$, Sox 2 , Oct 4 and Nanog (11). For example, the transcriptional promoter region of ROR is directly affected by pluripotency factors, OCT4, SOX2 and KLF4 (12). IncRNA-p21 binding to hnRNP-K assists hnRNP-K to localize and inhibit p53-regulated genes, and is a p53-dependent transcriptional response inhibitor (13). Competing endogenous RNAs (ceRNAs) regulate gene expression through competitive binding of microRNA. By providing ceRNA or natural microRNA sponge-like functions, IncRNAs are important post-transcriptional regulators of gene expression, regulating microRNAs and competitively inhibiting important receptors involved in various cellular biological activities (14). For example, lncRNA-loc285194, growth-arrest specific 5 (GAS5) and HOTAIR appear to function as competitive endogenous RNAs participating in the inhibition of tumor development (15-17). GAS5 also has the ability to simulate DNA and compete with steroid receptors in cells, which regulates steroid-mediated transcriptional regulation, growth arrest and apoptosis (18). In human meningioma cells, IncRNA maternally expressed gene 3 (MEG3) stimulates p53-mediated transactivation and inhibits tumor proliferation by inducing apoptosis (19), which may be associated with its ability to downregulate MDM2 expression as demonstrated by Zhou et al (20). Certain natural antisense transcripts are important IncRNAs that may be paired with complementary RNAs to form sense-antisense double-stranded RNAs. This causes the degradation or translational inhibition of target mRNA. For example, IncRNA-Wrap53 is a natural antisense transcript of p53. The highly conserved Wrap53 has been demonstrated to regulate endogenous p53 mRNA levels and further induce p53 protein expression by targeting the 5'-untranslated region of p53 mRNA (21). p21-associated lncRNA DNA-damage activated (PANDA) is an IncRNA located $\sim 5 \mathrm{kB}$ upstream of the CDKN1A TSS gene, and is induced by specific DNA damage. PANDA is also a p53-associated regulatory lncRNA involved in cell cycle progression and apoptosis (22). The ectopic expression of IncRNA is involved in numerous disease processes, but the underlying molecular mechanism is not yet fully understood. Table I lists the lncRNAs that interact with the $\mathrm{p} 53$ pathway in various types of human cancer.

\section{IncRNA and the NF-кB signaling pathway}

$\mathrm{NF}-\kappa \mathrm{B}$ is a widely expressed pleiotropic transcription factor. It is a heterotrimer composed of p50, p65 and IкB. The NF- $\kappa B$ signaling pathway is activated by a variety of extracellular stimuli, serving a central role in transcriptional regulation, and in the expression and regulation of various genes. It is a 


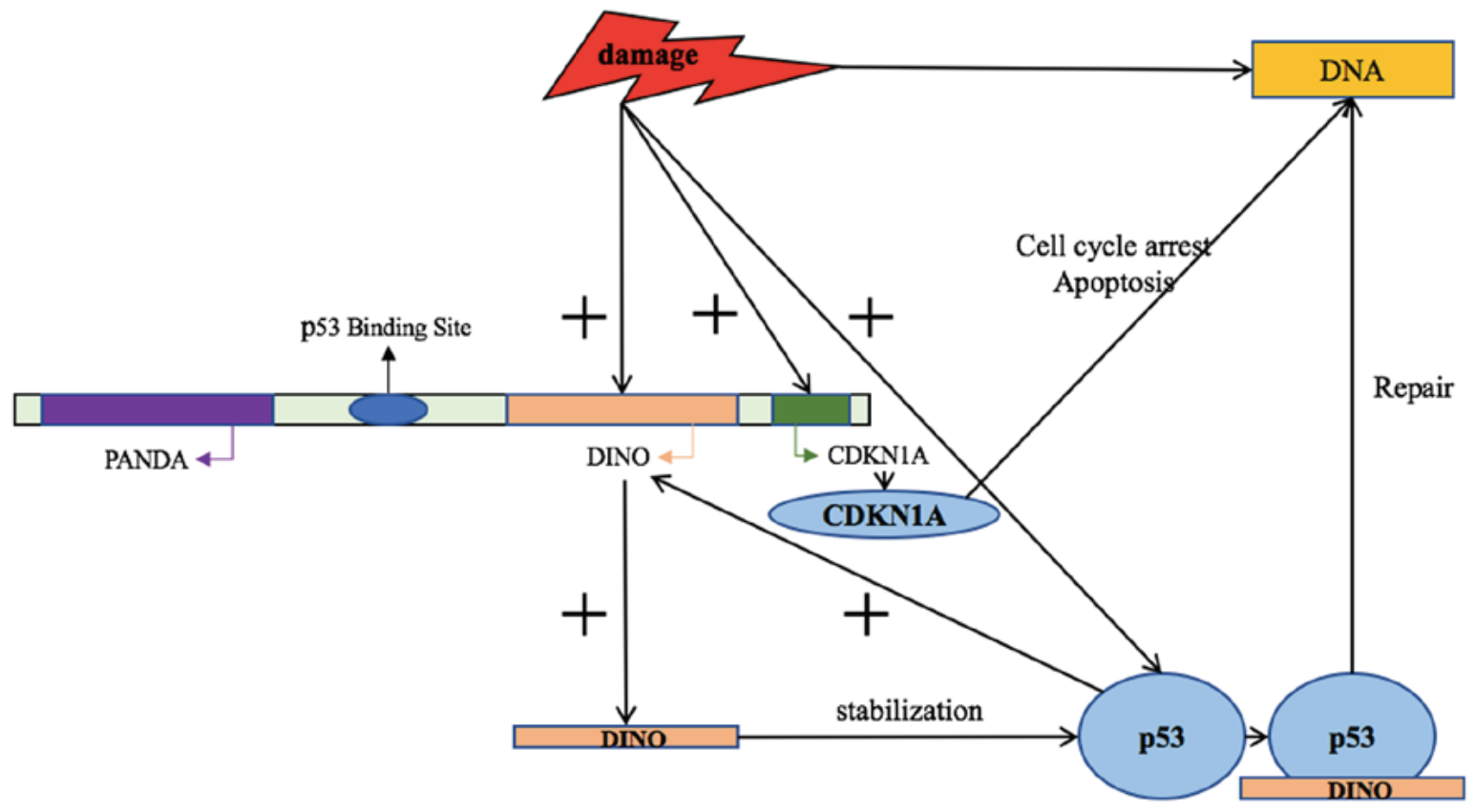

Figure 1. A typical lncRNA feedback loop regulatory mechanism. After p53 recognizes and responds to DNA damage, it can interact with DINO to enhance stability, and transcriptional activation of downstream gene expression including DINO. The increase in DINO levels, in turn, binds and stabilizes the p53 protein, creating a positive feedback loop that cascades the damage signal within the nucleus, thereby regulating the p53 signaling pathway's response to DNA damage. +, upregulation; PANDA, p21-associated lncRNA DNA-damage activated; DINO, damage induced noncoding; CDKN1A, cyclin dependent kinase inhibitor $1 \mathrm{~A}$.

marker of cell activation, and mediates a variety of biological processes, including inflammation, cell proliferation and tumor metastasis. The $\mathrm{NF}-\kappa \mathrm{B}$ pathway is regulated by various lncRNAs.

IncRNA-Lethe was the first IncRNA identified to be involved in regulation of the $\mathrm{NF}-\kappa \mathrm{B}$ signaling pathway. In human 293 cells, Lethe is selectively induced by pro-inflammatory cytokines through the NF- $\mathrm{BB}$ pathway, and acts on RelA (the p65 subunit of NF- $\kappa$ B) to inhibit RelA-DNA binding and subsequently target gene activation (23). Lethe has an active role in regulating the $\mathrm{NF}-\kappa \mathrm{B}$ pathway and is involved in inflammation through a typical negative feedback mechanism. Activated NF- $\mathrm{BB}$ promotes the expression of Lethe, and Lethe directly inhibits this pathway by interacting with RelA, thereby reducing the production of various inflammatory proteins (23). A novel lncRNA, namely nuclear transcription factor $\mathrm{NF}-\kappa \mathrm{B}$ interacting lncRNA (NKILA), which participates in the inhibition of breast cancer metastasis through the $\mathrm{NF}-\kappa \mathrm{B}$ signaling pathway, was discovered by analyzing a large number of lncRNAs in human breast cancer (24). NF- $\kappa \mathrm{B}$ upregulates the expression of NKILA by binding to the promoter of NKILA, and a large quantity of NKILA is able to bind to NF- $\kappa \mathrm{B} / \mathrm{I} \kappa \mathrm{B}$ to form a stable complex, thus directly masking the phosphorylation site of $\mathrm{I} \kappa \mathrm{B}$ to prevent IKK-mediated phosphorylation of I $\mathrm{B}$ and activation of $\mathrm{NF}-\kappa \mathrm{B}$. The negative feedback of NKILA and NF- $\kappa \mathrm{B}$ serves a key role in preventing overactivation of the NF- $\kappa \mathrm{B}$ pathway in inflammation-stimulated mammary epithelial cells. However, highly expressed microRNA-103/107 mediates the degradation of NKILA, which results in overactivation of the NF- $\kappa \mathrm{B}$ pathway, thus contributing to cancer metastasis and poor patient outcome (24). As a key enzyme in prostaglandin synthesis, COX-2 serves an important role in the prognosis of tumors, particularly neoangiogenesis and tumor progression $(25,26)$. lncRNA p50-associated COX-2 extragenic RNA (PACER), localized in the nucleus, binds directly to free p50, inhibits the formation of homodimers, promotes the formation of heterodimers, increases the transcription enhancement effect and increases the expression of COX-2 (27). Pearson et al (28) achieved results, which support these observations, whereby primary human osteoarthritic chondrocytes treated with IL- $1 \beta$ rapidly induced the formation of PACER, indicating that PACER expression is associated with COX2. In addition to PACER, the lncRNA cyclooxygenase 2 (COX2) locus near the COX 2 gene is essential for the transcription of $\mathrm{NF}-\kappa \mathrm{B}-$ associated late inflammatory genes in endotoxin-treated mouse macrophages (29). In the nucleus, MALAT1 interacts with the P65-p50 heterodimer to inhibit downstream TNF/ IL-6 expression. Bioinformatics analysis has revealed that MALAT1 affects $N F-\kappa B / R e l A$ activity in the epithelialmesenchymal transition process (30). The abnormal expression of HOTAIR in ovarian cancer induces NF- $\kappa \mathrm{B}$ activation by inhibiting I $\kappa-\mathrm{B} \alpha$ in the DNA damage response. It also increases the expression of MMP-9 and IL-6, key target genes of NF- $\kappa \mathrm{B}$, and serves an important role in DNA damage response, cell senescence and chemotherapy resistance (31). In addition, certain lncRNAs regulate signaling pathways indirectly through signaling elements or associated upstream molecules in the NF- $\kappa \mathrm{B}$ pathway. For example, MIR31HG is frequently deleted in glioblastoma, and significantly reduces the levels of micro (mi)RNA-31, while loss of miRNA-31 expression enhances NF- $\kappa$ B signaling by targeting TRADD, its upstream activator, and promotes tumor growth (32). C2dat1 promotes neural cell survival by enhancing CAMK2D expression and activating the $\mathrm{NF}-\kappa \mathrm{B}$ pathway (33). Expression of IL $1 \beta$-eRNA, IL1 $\beta$-RBT46, AS-IL1 $\alpha$, ANRIL, THRIL and IL7R is induced 
Table I. IncRNAs interact with p53 signaling pathway in cancers.

\begin{tabular}{|c|c|c|c|c|c|}
\hline Author, year & $\operatorname{lncRNA}$ & Associated disease & Function & Effect on pathway & (Refs.) \\
\hline Liu et al, 2013 & LOC285194 & Osteosarcoma & $\begin{array}{l}\text { Inhibit tumor cell } \\
\text { growth }\end{array}$ & Positive & (15) \\
\hline Tano et al, 2017 & MALAT1 & Lung adenocarcinoma & Inhibit cell cycle arrest & Negative & (90) \\
\hline Yang et al, 2016 & ROR & Colorectal cancer & $\begin{array}{l}\text { Decrease sensitivity } \\
\text { to radiotherapy }\end{array}$ & Negative & (91) \\
\hline $\begin{array}{l}\text { Chen et al, } 2016 \\
\text { Zhu et al, } 2015\end{array}$ & MEG3 & Hepatoma & $\begin{array}{l}\text { Inhibit proliferation } \\
\text { and apoptosis }\end{array}$ & Positive & $(92,95)$ \\
\hline Li et al, 2016 & MEG3 & Glioma & Inhibit tumorigenesis & Positive & (93) \\
\hline Lu et al, 2013 & MEG3 & $\begin{array}{l}\text { Non-small cell } \\
\text { lung cancer }\end{array}$ & $\begin{array}{l}\text { Inhibit proliferation } \\
\text { and apoptosis }\end{array}$ & Positive & (94) \\
\hline Sun et al, 2016 & MEG3 & Breast cancer & $\begin{array}{l}\text { Inhibit proliferation, } \\
\text { metastasis and invasion }\end{array}$ & Positive & (96) \\
\hline Zhang et al, 2014 & TUG1 & $\begin{array}{l}\text { Non-small cell } \\
\text { lung cancer }\end{array}$ & Inhibit tumorigenesis & Positive & (97) \\
\hline Huang et al, 2015 & UCA1 & Breast cancer & Promote tumorigenesis & Negative & (98) \\
\hline Zhai et al, 2016 & HOTAIR & $\begin{array}{l}\text { Non-small cell } \\
\text { lung cancer }\end{array}$ & $\begin{array}{l}\text { Promote proliferation } \\
\text { and invasion }\end{array}$ & Negative & (99) \\
\hline Su et al, 2017 & PRAL & Lung cancer & Inhibit proliferation & Positive & (100) \\
\hline Gong et al, 2014 & LOC401317 & $\begin{array}{l}\text { Nasopharyngeal } \\
\text { carcinoma }\end{array}$ & Inhibit proliferation & Positive & (101) \\
\hline Zhai et al, 2015 & ASLNC04080 & $\begin{array}{l}\text { Endometrial } \\
\text { carcinoma }\end{array}$ & $\begin{array}{l}\text { Promote proliferation } \\
\text { and invasion }\end{array}$ & Negative & $(102)$ \\
\hline Thorenoor et al, 2016 & ZFAS1 & Colorectal cancer & Promote proliferation & Negative & (103) \\
\hline
\end{tabular}

by the $\mathrm{NF}-\kappa \mathrm{B}$ signaling pathway, and regulates the expression of NF- $\mathrm{B}$-associated target genes (34-38). Table II lists the lncRNAs that interact with the NF- $\mathrm{B}$ pathway in cancer.

\section{IncRNA and the Wnt signaling pathway}

The Wnt gene was first named Int1, because its activation is dependent on the insertion of the mouse breast cancer-associated virus gene (39). Since then, a large number of studies have reported that Int1 serves an important role in the normal embryonic development of mice and is equivalent to the Wingless gene of drosophila. Therefore, combining Wingless with Int1 it was named Wnt. The Wnt signaling pathway is an evolutionarily highly conserved signaling system involved in important physiological processes, including embryonic development, tissue differentiation and cell homeostasis $(40,41)$. Specific lncRNAs associated with the Wnt signaling pathway are discussed below.

Numerous IncRNAs target and affect the accumulation of $\beta$-catenin, a key molecule that acts on the Wnt pathway, thereby regulating the expression of Wnt target genes and the function of cancer cells $(42,43)$. Numerous lncRNAs regulate target genes to promote tumorigenesis and development. In breast cancer, patients exhibiting high CCAT2 expression have a significantly poorer prognosis and lower overall survival rate compared with patients with low CCAT2 expression (44). A previous study on MCF-7 and MDA-MB231 breast cancer cells demonstrated that the suppression of
CCAT2 expression decreases the levels of $\beta$-catenin in the cytoplasm and nucleus, and reduces the expression of CCND1 and c-myc, which are classic downstream genes of the Wnt/ $\beta$ catenin signaling pathway. These results indicate the possible role of CCAT2 in breast cancer (44). The abnormal expression of HOTAIR has been demonstrated in certain types of human cancer. In colorectal cancer, Wnt/0205-catenin signaling is inhibited by HOTAIR-knockdown and miR-203a-3p overexpression (45). The downregulation of HOTAIR expression is essential for reducing cell proliferation and chemoresistance via modulation of miR-203a-3p expression levels and the activity of the Wnt/0205-catenin signaling pathway (45). lncRNA-CRNDE is significantly overexpressed in renal cell carcinoma. Elevated CRNDE expression may regulate the PI3K/Akt/GSK3b signaling pathway, increase the level of $\beta$-catenin in the nucleus, and ultimately regulate the expression of the Wnt target gene to regulate the proliferation of renal cancer cells (46). IncRNA-TCF7 promotes the self-renewal and proliferation of hepatocellular carcinoma cells by activating the Wnt signaling pathway. It may be that TCF7 recruits SWI/SNF complexes to act on its own promoter to regulate expression and activate the Wnt pathway (47). Similarly, numerous studies have reported that lncRNAs inhibit tumorigenesis. In a large number of non-small cell lung cancer tissue samples, low expression of AK126698 often predicts larger tumor diameter and advanced tumor stage. Conversely, an increase in AK126698 expression targets Frizzled-8, one of the receptors acting of the Wnt/ $\beta$-catenin signaling pathway, 
Table II. lncRNAs interact with NF- $\kappa \mathrm{B}$ signaling pathway in cancers.

\begin{tabular}{|c|c|c|c|c|c|}
\hline Author, year & lncRNA & Associated disease & Function & Effect on pathway & (Refs.) \\
\hline Rajbhandari et al, 2015 & MIR31HG & Glioblastoma & Inhibit tumor growth & Negative & $(32)$ \\
\hline Chen et al, 2016 & MEG3 & Hepatoma & Inhibit cell apoptosis & Positive & $(92)$ \\
\hline Özeş et al, 2016 & HOTAIR & Ovarian cancer & $\begin{array}{l}\text { Promote cellular senescence } \\
\text { and chemotherapy resistance }\end{array}$ & Positive & $(31)$ \\
\hline Li et al, 2017 & HOTAIR & Colorectal cancer & Promote 5FU resistance & Positive & $(104)$ \\
\hline Liao et al, 2018 & H19 & $\begin{array}{l}\text { Malignant } \\
\text { melanoma }\end{array}$ & $\begin{array}{l}\text { Promote the metastasis } \\
\text { and invasion }\end{array}$ & Positive & $(105)$ \\
\hline Liu et al, 2015 & NKILA & Breast cancer & Inhibit metastasis & Negative & (24) \\
\hline Yang et al, 2018 & NKILA & Laryngeal cancer & $\begin{array}{l}\text { Inhibit proliferation } \\
\text { and metastasis } \\
\text { Enhance radiosensitivity }\end{array}$ & Negative & $(106)$ \\
\hline Bian et al, 2017 & NKILA & $\begin{array}{l}\text { Malignant } \\
\text { melanoma }\end{array}$ & $\begin{array}{l}\text { Inhibit invasion } \\
\text { and metastasis }\end{array}$ & Negative & $(107)$ \\
\hline Huang et al, 2016 & NKILA & $\begin{array}{l}\text { Tongue squamous } \\
\text { cell carcinoma }\end{array}$ & $\begin{array}{l}\text { Inhibit migration } \\
\text { and invasion }\end{array}$ & Negative & $(108)$ \\
\hline Ma et al, 2018 & DANCR & Glioma & Promote cisplatin resistance & Positive & $(109)$ \\
\hline
\end{tabular}

inhibiting the proliferation and metastasis of cancer cells and inducing apoptosis (48). The expression of lncRNA-CTD903 is significantly upregulated in human colorectal cancer and may be used as an independent prognostic factor for colorectal cancer. When CTD903 was knocked down in the RKO and SW480 cell lines, the invasion and metastasis of the tumor cells is increased, and epithelial-mesenchymal transition-like characteristics are exhibited (49). Further results demonstrated that downregulated CTD903 expression allows the Wnt/ $\beta$-catenin signaling pathway to be more easily activated, increasing the expression of transcription factors, Twist and Snail, as well as the protein expression of the mesenchymal marker, Vimentin, and reducing that of the epithelial marker, ZO-1 (49). Chemotherapy resistance can result in poor prognosis. Furthermore, lncRNAs serve a role in cell resistance. The level of lncRNA-Meg3 is significantly lower in the cisplatin-resistant lung cancer cell line, A549/DDP, compared with that in the A549 cell line (50). Further results demonstrated that the upregulation of Meg3 expression in vitro increases the sensitivity of the A549/DDP lung cancer cell line to cisplatin. However, the sensitivity of A549 cells to cisplatin decreased following RNA interference downregulation of Meg3 expression. Researchers hypothesized that Meg3 mediates increased cell cycle arrest and apoptosis by regulating $\mathrm{p} 53, \beta$-catenin and survivin, resulting in increased sensitivity to chemotherapy (50). In osteosarcoma, HOTTIP induces tumor occurrence and resistance by activating the Wnt signaling pathway, which may be a potential target for the treatment of osteosarcoma (51). Table III lists the lncRNAs that interact with the Wnt signaling pathway and their general roles in cancer.

\section{IncRNA and the Notch signaling pathway}

The notch signaling pathway is a highly evolutionarily conserved cell signaling pathway. It mediates direct cell- cell contact and affects the normal morphogenesis of cells. It regulates differentiation of multipotent progenitor cells, apoptosis, cell proliferation and the formation of cell borders (52). lncRNA also interacts with the Notch signaling pathway and affects tumor progression.

It has been reported that the non-coding sequences that accompany the genes are often involved in the regulation of peripheral genes. In the human genome, lncRNA-NALT was identified at a distance of $\sim 100$ bases from the NOTCH1 gene. In T-cell acute lymphoblastic leukemia cells, increased expression of NALT significantly promotes cell proliferation. It may be that NALT activates transcription in the Notch pathway and regulatory elements in the nucleus (53). IncRNA-SNHG12 expression is significantly elevated in osteosarcoma tissues and cell lines, and predicts poor prognosis. A study of the biological function of SNHG12 in the 143B and U2OS cell lines revealed that the downregulation of SNHG12 inhibits cell proliferation by blocking the G0/G1 phase of the cell cycle, and reduces the potential for cell invasion and metastasis. SNHG12 sponges miR-195-5p in osteosarcoma cells, similarly to endogenously-competent RNA, to regulate Notch2 gene expression, thereby affecting signal transduction in the Notch pathway (54). In a study of CRC specimens, and matched adjacent normal tissues and CRC cell lines, the expression of FOXD2-AS1 was significantly increased in CRC tissues as well as in CRC cell lines, and downregulation of FOXD2-AS1 expression suppressed proliferation, invasion and migration in vitro. Further study examined associated markers of the epithelial-mesenchymal transition and Notch signaling pathways, and confirmed that the two pathways are inactivated in CRC cells following FOXD2-AS1-knockdown (55). When studying the expression profile of 1ncRNA-MEG3 and the two Notch pathway-associated molecules, Notch1 and Hes1, in human endometrial tissues and cell lines, Guo et al (56) reported that, compared with the normal control group, MEG3 expression is significantly downregulated in cancer 
Table III. IncRNAs that interact with the Wnt signaling pathway in cancer.

\begin{tabular}{|c|c|c|c|c|c|}
\hline Author, year & IncRNA & Associated disease & Function & $\begin{array}{l}\text { Effect on } \\
\text { pathway }\end{array}$ & (Refs.) \\
\hline Cai et al, 2015 & CCAT2 & Breast cancer & $\begin{array}{l}\text { Promote cell growth } \\
\text { and tumor formation }\end{array}$ & Positive & $(44)$ \\
\hline Shao et al, 2016 & CRNDE & Renal cell carcinoma & Promote cell proliferation & Positive & (46) \\
\hline Wang et al, 2015 & TCF7 & $\begin{array}{l}\text { Hepatocellular } \\
\text { carcinoma }\end{array}$ & $\begin{array}{l}\text { Promote liver cancer stem cells } \\
\text { self-renewal and tumor propagation }\end{array}$ & Positive & $(47)$ \\
\hline Fu et al, 2016 & AK126698 & $\begin{array}{l}\text { Non-small cell } \\
\text { lung cancer }\end{array}$ & Inhibit proliferation and migration & Negative & $(48)$ \\
\hline Yuan et al, 2016 & CTD903 & Colorectal cancer & Inhibit cancer invasion and migration & Negative & $(49)$ \\
\hline Xia et al, 2015 & MEG3 & Lung cancer & Enhance chemosensitivity & Negative & $(50)$ \\
\hline Rajbhandari et al, 2015 & TUG1 & $\begin{array}{l}\text { Oral squamous cell } \\
\text { carcinoma }\end{array}$ & $\begin{array}{l}\text { Promote proliferation } \\
\text { and metastasis }\end{array}$ & Positive & (110) \\
\hline Fan et al, 2014 & UCA1 & Bladder cancer & Promote chemoresistance & Positive & (43) \\
\hline Yang et al, 2016 & UCA1 & $\begin{array}{l}\text { Oral squamous cell } \\
\text { carcinoma }\end{array}$ & $\begin{array}{l}\text { Promote proliferation } \\
\text { and metastasis }\end{array}$ & Positive & (111) \\
\hline Xiao et al, 2018 & HOTAIR & Colorectal cancer & $\begin{array}{l}\text { Promote cell proliferation } \\
\text { and chemoresistance }\end{array}$ & Positive & $(45)$ \\
\hline Ge et al, 2013 & HOTAIR & $\begin{array}{l}\text { Esophageal squamous } \\
\text { cell cancer }\end{array}$ & Promote metastasis and invasion & Positive & $(112)$ \\
\hline Wu et al, 2017 & H19 & Colorectal cancer & Promote methotrexate resistance & Positive & (113) \\
\hline Cao et al, 2017 & CCAT1 & Epithelial ovarian cancer & $\begin{array}{l}\text { Promote metastasis and } \\
\text { poor prognosis }\end{array}$ & Positive & (114) \\
\hline Li et al, 2015 & HOTTIP & Osteosarcoma & Promote tumor occurrence & Positive & $(51)$ \\
\hline Fu et al, 2017 & HOTTIP & Pancreatic cancer & Promote tumorigenesis & Positive & (115) \\
\hline Yue et al, 2018 & CYTOR & Colon cancer & $\begin{array}{l}\text { Promote epithelial mesenchymal } \\
\text { transformation and metastasis }\end{array}$ & Positive & (116) \\
\hline Liu et al, 2016 & LET & Lung adenocarcinoma & $\begin{array}{l}\text { Inhibit tumor growth and epithelial } \\
\text { mesenchymal transformation }\end{array}$ & Negative & (117) \\
\hline Wang et al, 2017 & PTCSC3 & $\begin{array}{l}\text { Papillary thyroid } \\
\text { carcinoma }\end{array}$ & $\begin{array}{l}\text { Inhibit proliferation } \\
\text { and metastasis }\end{array}$ & Negative & $(118)$ \\
\hline Zhang et al, 2016 & CASC11 & Colorectal cancer & Promote proliferation and metastasis & Positive & (119) \\
\hline Zhang et al, 2017 & PCAT1 & $\begin{array}{l}\text { Extrahepatic } \\
\text { cholangiocarcinoma }\end{array}$ & Promote tumorigenesis & Positive & $(120)$ \\
\hline Wang et al, 2018 & LINC00968 & Non-small cell lung cancer & Promote tumorigenesis & Positive & (121) \\
\hline
\end{tabular}

tissue. However, the expression levels of Notch1 and Hes1 are significantly increased. Upregulation of MEG3 in tumor cells in vivo inhibits the growth of tumors by inhibiting the Notch pathway (56). The Notch pathway serves an important role in maintaining the pluripotency of glioma stem cells. The activation of Notch1 induces lncRNA-TUG1 expression in specific glioma cell lines. In the cytoplasm, TUG1 promotes cell self-renewal by decoying miR-145. In the nucleus, TUG1 binds YY1 by recruiting multi-comb complexes to allow sitespecific H3K27 histones to methylate, thereby inhibiting gene mutation. In addition, intravenous administration of TSG1 with antisense oligonucleotides induces the differentiation of glioma stem cell lines in vivo, and effectively inhibits their proliferation (57). Table IV lists the lncRNAs that interact with the Notch pathway in cancer.

\section{IncRNA and the PI3K/AKT signaling pathway}

AKT, also known as protein kinase B, is an important crossover molecule in multiple signaling pathways and is activated by various substances, including hormones, growth factors, cytokines and intercellular matrix. The PI3K/AKT signaling pathway is involved in important physiological activities, including cell proliferation and survival, and is associated with cancer, diabetes, rheumatoid arthritis and other diseases $(58,59)$. In recent years, the regulatory mechanism of lncRNAs in the PI3K/AKT pathway and the impact on diseases, have gradually been revealed.

Using a CRISPR/Cas9-based synergistic activation mediator system, Koirala et al (60) studied numerous lncRNAs that may affect AKT activity. They reported that 
Table IV. lncRNAs that interact with the Notch signaling pathway in cancer.

\begin{tabular}{|c|c|c|c|c|c|}
\hline Author, year & IncRNA & Associated disease & Function & Effect on pathway & (Refs.) \\
\hline Wang et al, 2015 & NALT & $\begin{array}{l}\text { Pediatric T cell acute } \\
\text { lymphoblastic leukemia }\end{array}$ & Promote proliferation & Positive & $(53)$ \\
\hline Zhou et al, 2018 & SNHG12 & Osteosarcoma & $\begin{array}{l}\text { Promote cell invasion } \\
\text { and migration }\end{array}$ & Positive & $(54)$ \\
\hline Yang et al, 2018 & FOXD2-AS1 & Colorectal cancer & $\begin{array}{l}\text { Promote cell proliferation } \\
\text { and migration }\end{array}$ & Positive & $(55)$ \\
\hline Guo et al, 2016 & MEG3 & Endometrial carcinoma & Inhibit proliferation & Negative & $(56)$ \\
\hline Cai et al, 2017 & HOTAIR & Pancreatic cancer & Promote tumor growth & Positive & $(17)$ \\
\hline Hang et al, 2015 & AK022798 & Gastric cancer & $\begin{array}{l}\text { Promotes } \\
\text { cisplatin-resistant }\end{array}$ & Positive & $(122)$ \\
\hline Lu et al, 2018 & FAM83H-AS1 & Colorectal carcinoma & Promote proliferation & Positive & $(123)$ \\
\hline Chen et al, 2017 & 00673 & Hepatocellular carcinoma & $\begin{array}{l}\text { Promote proliferation } \\
\text { and metastasis }\end{array}$ & Positive & $(124)$ \\
\hline
\end{tabular}

lncRNA-AK023948 is a positive regulator of the AKT pathway. In malignant cells, upregulation of AK023948 and DHX9 expression promotes the activation of the AKT pathway. Furthermore, they may interact with ATP-dependent RNA helicase A (RHA/DHX9) and P58 to participate in the AKT pathway, and respond to growth factors or internal environmental stimuli, such as acid-alkali poisoning (60). It has been reported that the upregulation of lncRNA-AB073614 expression in ovarian cancer $(61)$ and glioma $(62,63)$ is associated with the occurrence and development of tumors. In vitro, the knockdown of AB073614 expression significantly inhibits the proliferation, differentiation, apoptosis, metastasis and invasion of colorectal cancer cells, and results in increased rates of apoptosis and G1 phase cell cycle arrest, while overexpression of AB073614 results in the opposite effects. The agonist (740Y-P) and an inhibitor (LY294002) of the PI3K/AKT signaling pathway were used to demonstrate the role of AB073614 in colorectal tumor cells (64). Using similar research methods, a team reported that PlncRNA-1 (65) and NEAT1 (66) act on the PI3K/AKT pathway, and participate in the proliferation and apoptosis of colorectal cancer cells. A study on 102 gastric cancer tissues and adjacent normal tissues indicated that the abnormal expression of 1ncRNA-UCA1 serves an important role in the development, metastasis and invasion of gastric cancer. In vitro and in vivo experiments demonstrated that the molecular mechanism of UCA1 regulation on the PI3K/AKT pathway occurs by regulating PI3K-Akt-mTOR signaling proteins and downstream molecules to influence the growth process of gastric cancer cells (67). MALAT1 regulates multiple signaling pathways. In breast and ovarian cancer, it was recently discovered that MALAT1 influences the epithelial-mesenchymal transition and regulates the tumorigenicity of cells by targeting the PI3K/AKT pathway $(68,69)$. In bovine epithelial cells, lncRNA-H19 also affects the epithelial-mesenchymal transition via PI3K/AKT regulation (70). Table V lists the IncRNAs associated with the PI3K/AKT signaling pathway in cancer.

\section{IncRNA and the MAPK signaling pathway}

The MAPK pathway is a classical signaling pathway, and is involved in the regulation of cell proliferation, differentiation, transformation and apoptosis. The MAPK pathway is associated with the occurrence of various diseases, including inflammation and tumors, by phosphorylating nuclear transcription factors, cytoskeletal proteins, and enzymes. MAPK signaling primarily includes four pathways: ERK, JNK/SAPK, P38 and ERK5/BMK1. The ERK, JNK, P38 and ERK5/BMK1 pathways can be activated by different stimuli, and there is wide crosstalk between these pathways, resulting in mutual synergy or inhibition between them. As important regulatory genes, numerous lncRNAs have been identified to regulate the MAPK pathway.

An important role of the SNHG12-miR-181a-MAPK/Slug axis was described in multidrug resistance in non-small cell lung cancer cells. In non-small cell lung cancer cells, silencing of lncRNA-SNHG12 upregulates miR-181a expression, and inhibits MAPK1 and MAP2K1 expression. This is accompanied by decreased phosphorylation of MAPK1 and MAP2K1, and decreased Slug expression levels. Ultimately, lncRNA-SNHG12 inhibits the activation of the MAPK/Slug pathway and increases the drug sensitivity of tumor cells (71). Similarly, lncRNA-XIST acts via microRNA to influence the activation of pathways. XIST regulates MAPK1 by targeting miR-194-5p-like ceRNA and reducing its expression. Silenced XIST inhibits the proliferation of hepatoma cells and reduces their invasiveness (72). In previous in vitro and in vivo studies of gallbladder carcinoma, the knockdown of MALAT1 was demonstrated to reduce the phosphorylation of MEK1/2, ERK1/2, MAPK and JNK $1 / 2 / 3$, resulting in significant inhibition of the ERK/MAPK pathway. The metastasis and invasiveness of cancer cells is also weakened simultaneously (73). In a cecal ligation and puncture (CLP) rat model, the expression levels of $\mathrm{p} 38, \mathrm{MAPK}$ and $\mathrm{NF}-\kappa \mathrm{B}$ protein were significantly higher in the CLP group compared with that in the sham group (74). Overexpression of MALAT1 alone 
Table V. lncRNAs that interact with the PI3K/AKT signaling pathway in cancer.

\begin{tabular}{|c|c|c|c|c|c|}
\hline Author, year & lncRNA & Associated disease & Function & $\begin{array}{l}\text { Effect on } \\
\text { pathway }\end{array}$ & (Refs.) \\
\hline Cheng et al, 2015 & AB073614 & Ovarian cancer & Promote tumorigenesis & Positive & $(61)$ \\
\hline Wang et al, 2017 & AB073614 & Colorectal cancer & Promote tumor growth & Positive & (64) \\
\hline Song et al, 2017 & PlncRNA-1 & Colorectal carcinoma & Promote tumor growth & Positive & $(65)$ \\
\hline Peng et al, 2017 & NEAT1 & Colorectal cancer & Promote tumor growth & Positive & $(66)$ \\
\hline Zhang et al, 2017 & MEG3 & Glioma & Inhibit tumorigenesis & Negative & $(125)$ \\
\hline Li et al, 2018 & UCA1 & Osteosarcoma & Promote proliferation & Positive & $(126)$ \\
\hline Yun et al, 2016 & TUG1 & Osteosarcoma & Promote proliferation & Positive & $(127)$ \\
\hline Yan et al, 2016 & HOTAIR & Gastric cancer & Promotes cisplatin resistance & Positive & $(128)$ \\
\hline Wang et al, 2017 & HOTAIR & Chronic myeloid leukemia & Promote imatinib resistance & Positive & $(129)$ \\
\hline Jiang et al, 2017 & DANCR & Osteosarcoma & Promote tumor progression & Positive & $(130)$ \\
\hline Yuan et al, 2018 & HOTTIP & Papillary thyroid carcinoma & Promote proliferation & Positive & $(131)$ \\
\hline Xue et al, 2016 & GAS5 & Prostate cancer & Inhibit tumor growth & Negative & $(132)$ \\
\hline Huang et al, 2016 & Xist & Breast cancer & Inhibit tumor growth & Negative & $(133)$ \\
\hline Lu et al, 2017 & HULC & Chronic myeloid leukemia & Promote proliferation & Positive & $(134)$ \\
\hline Wang et al, 2017 & HULC & Bladder cancer & Promote proliferation & Positive & $(135)$ \\
\hline He et al, 2017 & NONHSAT062994 & Colorectal cancer & Inhibit tumor growth & Negative & $(136)$ \\
\hline Han et al, 2018 & $\mathrm{p} 21$ & Osteosarcoma & Inhibit proliferation & Negative & $(137)$ \\
\hline Wang et al, 2018 & AB209630 & $\begin{array}{l}\text { Pancreatic ductal } \\
\text { adenocarcinoma }\end{array}$ & $\begin{array}{l}\text { Inhibit gemcitabine } \\
\text { resistance }\end{array}$ & Negative & $(138)$ \\
\hline Wang et al, 2017 & MIR31HG & $\begin{array}{l}\text { Non-small cell } \\
\text { lung cancer }\end{array}$ & $\begin{array}{l}\text { Promote gefitinib } \\
\text { resistance }\end{array}$ & Positive & $(139)$ \\
\hline Chen et al, 2017 & PTENP1 & Breast cancer & $\begin{array}{l}\text { Inhibit proliferation } \\
\text { and metastasis }\end{array}$ & Negative & $(140)$ \\
\hline
\end{tabular}

Table VI. lncRNAs that interact with the MAPK signaling pathway in cancer.

\begin{tabular}{|c|c|c|c|c|c|}
\hline Author, year & lncRNA & Associated disease & Function & $\begin{array}{l}\text { Effect on } \\
\text { pathway }\end{array}$ & (Refs.) \\
\hline Wang et al, 2017 & SNHG12 & Non-small cell lung cancer & Promote multidrug resistance & Positive & $(71)$ \\
\hline Kong et al, 2017 & Xist & Hepatocellular carcinoma & $\begin{array}{l}\text { Promote proliferation, } \\
\text { migration and invasion }\end{array}$ & Positive & $(72)$ \\
\hline Wu et al, 2014 & MALAT1 & Gallbladder cancer & Promote proliferation and metastasis & Positive & $(73)$ \\
\hline Liu et al, 2017 & MALAT1 & Retinoblastoma & Promote proliferation and metastasis & Positive & $(143)$ \\
\hline Jiang et al, 2015 & BANCR & Lung carcinoma & Promotes proliferation and migration & Positive & $(76)$ \\
\hline Li et al, 2014 & BANCR & Malignant melanoma & Promote proliferation & Positive & (77) \\
\hline Huang et al, 2015 & TUG1 & Non-small cell lung cancer & Inhibit tumorigenesis & Negative & (98) \\
\hline Chen et al, 2017 & PTENP1 & Breast cancer & Inhibit proliferation and metastasis & Negative & $(140)$ \\
\hline Li et al, 2018 & HOTAIR & Cervical cancer & Promote metastasis and invasion & Positive & $(141)$ \\
\hline Gao et al, 2017 & CCAT1 & Medulloblastoma & Promote proliferation and metastasis & Positive & $(142)$ \\
\hline Huang et al, 2015 & DBH-AS1 & Hepatocellular carcinoma & Promote proliferation & Positive & $(144)$ \\
\hline Peng et al, 2017 & RoR & Breast cancer & $\begin{array}{l}\text { Promote estrogen-independent } \\
\text { tumor growth }\end{array}$ & Positive & $(145)$ \\
\hline Wu et al, 2017 & NEAT1 & Non-small cell lung cancer & Promote tumorigenesis & Positive & $(146)$ \\
\hline Peng et al, 2016 & CCHE1 & Hepatocellular carcinoma & Promote carcinogenesis & Positive & $(147)$ \\
\hline
\end{tabular}

significantly increases the levels of $\mathrm{p} 38 / \mathrm{MAPK}$ and NF- $\mathrm{NB}$. An elaborative study demonstrated that MALAT1 mediates the development of heart failure and the inflammatory response through the activation of $\mathrm{p} 38 / \mathrm{MAPK} / \mathrm{NF}-\kappa \mathrm{B}$. Furthermore, 
in the inflammatory response to sepsis, p38/MAPK/NF- $\kappa$ B may be downstream of MALAT1 signaling (74). In neurogenic hyperplasia of neuroblastoma-derived Neuro-2a cells, silencing of MALAT1 results in significant activation of the MAPK pathway, and abnormal activation of the peroxisome proliferator-activated receptor and the p53 pathway (75). Thus, the same lncRNA appears to exhibit different effects in different types of tumors. When IncRNA-BANCR is deleted in lung cancer cells, the proliferation and metastasis of cancer cells is increased. In addition, when the expression of BANCR is increased, the proliferation of lung cancer cells is inhibited, acting as a tumor suppressor gene (76). In in vivo and in vitro experiments on malignant melanoma, tumor growth is inhibited following BANCR-knockout. The underlying mechanism may involve the silencing of BANCR making it difficult to activate the MAPK pathway, and to inhibit important components of the pathway, ERK1/2 and JNK (77). Table VI lists the lncRNAs that interact with the MAPK pathway in cancer.

\section{Discussion}

The regulatory roles of lncRNAs are diverse and complex, and the current understanding of them is limited. The ENCODE research project identified $<10,000$ lncRNAs in the human genome (78), but only 100 lncRNAs are known to be biologically functional. This is not only due to limited research techniques, but also the nature of lncRNAs. The intracellular abundance of lncRNA is typically low, and the function between different species is not conserved. For example, the human HOTAIR gene has a transregulatory effect on the HOXD gene, but this function is not observed in mice (79). Previous studies have demonstrated that lncRNAs primarily act as signal transduction molecules, decoys, transcription factors and scaffolds, interacting with proteins, DNA, RNA or other molecules to participate in transcriptional regulation, post-transcriptional regulation and epigenetic regulation of genes. The transcriptional regulation and posttranscriptional regulation of lncRNAs have been detailed, but their regulatory role in epigenetics is also an important function, and lncRNA-Xist is an interesting example $(80,81)$. lncRNA-Xist is able to extensively bind to the X-chromosome through an interaction with polycomb repressive complex 2 , leading to the inactivation of the X-chromosome $(82,83)$. Recently, the novel silencing effect of Xist on the $\mathrm{X}$-chromosome identified by Chen et al (84) has been debated. In the experiments by Chen et al (84), it was demonstrated that Xist interacts with Lamin B Receptor (LBR), a nuclear inner membrane protein involved in the establishment of the three-dimensional structures of chromosomes by regulating the anchoring of chromatin in the nucleus. It was hypothesized that the combination of Xist and LBR triggers alterations to the three-dimensional structure of the X-chromosome and thus participates in the silencing of the X-chromosome. This hypothesis was validated by constructing stable cell lines, LBS-Xist and LBS-Xist-BoxB, associated with Xist and LBR (84). However, a study by Wang et al questioned these findings. According to the analysis of the original sequencing data, it was considered that the Xist-associated stable cell lines, LBS-Xist and LBS-Xist-BoxB, were unsuccessfully constructed, and the sequencing depth and data normalization were also problematic (85). In response, the original research team provided more detailed evidence to confirm the results of their own research (86). Similar disputes reflect that, although lncRNAs have been recognized as having important biological functions, our understanding remains far from thorough. However, rational academic controversy makes lncRNAassociated research more rigorous.

The lncRNA research surge began with HOTAIR, first reported in cell by Rinn et al, in 2007 (2). As the first lncRNA reported to have a transregulatory effect, it became a popular topic of research. However, researchers still question the role of HOTAIR in mouse development, and it is considered that it may not be as important as previous studies have described $(87,88)$. Furthermore, enrichment of the H3K27me3 modification of HOTAIR-regulated HOXD sites is not as pronounced as originally thought (79), and reports directly indicate that HOTAIR-knockout mice exhibit no apparent phenotypic changes (89). With some controversy, the differential expression of lncRNAs in a variety of types of cancer and chronic diseases have been confirmed. Several of the complex molecular mechanisms of lncRNA interaction have also been revealed. lncRNA research has improved our understanding of cell biological regulatory network, which is a step towards understanding the molecular mechanisms involved in disease. Although lncRNAs are currently at an early stage of research as potential targets for the treatment of cancer, certain small molecule lncRNAs have entered clinical trials as targeted drugs. It is expected that the targeted treatment of lncRNAs will become clinically available, improve the quality of life and prolong the survival of patients.

\section{Acknowledgements}

Not applicable.

\section{Funding}

This grant was supported by National Science Foundation Committee of China (grant no. 81502482 and 81672474), Zhejiang Provincial National Science Foundation Committee of China (grant no. LQ14H160017) and Zhejiang Provincial research projects of medical and healthy industries (grant nos. 2015KYB026, 2017KY193 and 2017KY210).

\section{Availability of data and materials}

Not applicable.

\section{Authors' contributions}

YS, JYZ and HHC consulted and preliminarily summarized the literature required for the manuscript. WS was the major contributor in writing the manuscript. ZFW contributed to the writing of the manuscript. DSH and JGZ approved the final version of the manuscript. All authors read and approved the final manuscript.

\section{Ethics approval and consent to participate}

Not applicable. 


\section{Patient consent for publication}

Not applicable.

\section{Competing interests}

The authors declare that they have no competing interests.

\section{References}

1. Okazaki Y, Furuno M, Kasukawa T, Adachi J, Bono H, Kondo S, Nikaido I, Osato N, Saito R, Suzuki H, et al: Analysis of the mouse transcriptome based on functional annotation of 60,770 full-length cDNAs. Nature 420: 563-573, 2002

2. Rinn JL, Kertesz M, Wang JK, Squazzo SL, Xu X, Brugmann SA Goodnough LH, Helms JA, Farnham PJ, Segal E, et al: Functional demarcation of active and silent chromatin domains in human HOX loci by noncoding RNAs. Cell 129: 1311-1323, 2007.

3. Tsai MC, Manor O, Wan Y, Mosammaparast N, Wang JK, Lan F, Shi Y, Segal E and Chang HY: Long noncoding RNA as modular scaffold of histone modification complexes. Science 329: 689-693, 2010

4. Amaral PP, Clark MB, Gascoigne DK, Dinger ME and Mattick JS: lncRNAdb: A reference database for long noncoding RNAs. Nucleic Acids Res 39 (Suppl 1): D146-D151, 2011.

5. St Laurent G, Wahlestedt C and Kapranov P: The Landscape of long noncoding RNA classification. Trends Genet 31: 239-251, 2015.

6. Wang Z, Gerstein M and Snyder M: RNA-Seq: A revolutionary tool for transcriptomics. Nat Rev Genet 10: 57-63, 2009.

7. Lane DP and Crawford LV: T antigen is bound to a host protein in SV40-transformed cells. Nature 278: 261-263, 1979.

8. Schmitt AM, Garcia JT, Hung T, Flynn RA, Shen Y, Qu K, Payumo AY, Peres-da-Silva A, Broz DK, Baum R, et al: An inducible long noncoding RNA amplifies DNA damage signaling. Nat Genet 48: 1370-1376, 2016.

9. Tripathi V, Shen Z, Chakraborty A, Giri S, Freier SM, Wu X, Zhang Y, Gorospe M, Prasanth SG, Lal A, et al: Long noncoding RNA MALAT1 controls cell cycle progression by regulating the expression of oncogenic transcription factor B-MYB. PLoS Genet 9: e1003368, 2013.

10. Zhang A, Zhou N, Huang J, Liu Q, Fukuda K, Ma D, Lu Z, Bai C, Watabe $\mathrm{K}$ and Mo YY: The human long non-coding RNA-RoR is a p53 repressor in response to DNA damage. Cell Res 23: 340-350, 2013.

11. Guttman M, Amit I, Garber M, French C, Lin MF, Feldser D, Huarte M, Zuk O, Carey BW, Cassady JP, et al: Chromatin signature reveals over a thousand highly conserved large noncoding RNAs in mammals. Nature 458: 223-227, 2009.

12. Loewer S, Cabili MN, Guttman M, Loh YH, Thomas K, Park IH, Garber M, Curran M, Onder T, Agarwal S, et al: Large intergenic non-coding RNA-RoR modulates reprogramming of human induced pluripotent stem cells. Nat Genet 42: 1113-1117, 2010.

13. Huarte M, Guttman M, Feldser D, Garber M, Koziol MJ, Kenzelmann-Broz D, Khalil AM, Zuk O, Amit I, Rabani M, et al: A large intergenic noncoding RNA induced by p53 mediates global gene repression in the p53 response. Cell 142: 409-419, 2010.

14. Tay Y, Rinn J and Pandolfi PP: The multilayered complexity of ceRNA crosstalk and competition. Nature 505: 344-352, 2014.

15. Liu Q, Huang J, Zhou N, Zhang Z, Zhang A, Lu Z, Wu F and Mo YY: LncRNA loc285194 is a p53-regulated tumor suppressor. Nucleic Acids Res 41: 4976-4987, 2013.

16. Zhang XF, Ye Y and Zhao SJ: LncRNA Gas5 acts as a ceRNA to regulate PTEN expression by sponging miR-222-3p in papillary thyroid carcinoma. Oncotarget 9: 3519-3530, 2017.

17. Cai H, Yao J, An Y, Chen X, Chen W, Wu D, Luo B, Yang Y, Jiang Y, Sun D, et al: LncRNA HOTAIR acts a competing endogenous RNA to control the expression of notch3 via sponging miR-613 in pancreatic cancer. Oncotarget 8: 3290532917, 2017.

18. Hudson WH, Pickard MR, de Vera IM, Kuiper EG, MourtadaMaarabouni M, Conn GL, Kojetin DJ, Williams GT and Ortlund EA: Conserved sequence-specific lincRNA-steroid receptor interactions drive transcriptional repression and direct cell fate. Nat Commun 5: 5395, 2014.
19. Zhang X, Gejman R, Mahta A, Zhong Y, Rice KA, Zhou Y, Cheunsuchon P, Louis DN and Klibanski A: Maternally expressed gene 3, an imprinted noncoding RNA gene, is associated with meningioma pathogenesis and progression. Cancer Res 70: 2350-2358, 2010.

20. Zhou Y, Zhong Y, Wang Y, Zhang X, Batista DL, Gejman R, Ansell PJ, Zhao J, Weng C and Klibanski A: Activation of p53 by MEG3 non-coding RNA. J Biol Chem 282: 24731-24742, 2007.

21. Mahmoudi S, Henriksson S, Corcoran M, Méndez-Vidal C, Wiman KG and Farnebo M: Wrap53, a natural p53 antisense transcript required for p53 induction upon DNA damage. Mol Cell 33: 462-471, 2009.

22. Hung T, Wang Y, Lin MF, Koegel AK, Kotake Y, Grant GD, Horlings HM, Shah N, Umbricht C, Wang P, et al: Extensive and coordinated transcription of noncoding RNAs within cell-cycle promoters. Nat Genet 43: 621-629, 2011.

23. Rapicavoli NA, Qu K, Zhang J, Mikhail M, Laberge RM and Chang HY: A mammalian pseudogene lncRNA at the interface of inflammation and anti-inflammatory therapeutics. eLife 2 : $\mathrm{e} 00762,2013$

24. Liu B, Sun L, Liu Q, Gong C, Yao Y, Lv X, Lin L, Yao H, Su F, $\mathrm{Li} \mathrm{D}$, et al: A cytoplasmic NF- $\kappa \mathrm{B}$ interacting long noncoding RNA blocks I $\kappa$ B phosphorylation and suppresses breast cancer metastasis. Cancer Cell 27: 370-381, 2015.

25. Rozic JG, Chakraborty C and Lala PK: Cyclooxygenase inhibitors retard murine mammary tumor progression by reducing tumor cell migration, invasiveness and angiogenesis. Int J Cancer 93: 497-506, 2001

26. Subbaramaiah K and Dannenberg AJ: Cyclooxygenase 2: A molecular target for cancer prevention and treatment. Trends Pharmacol Sci 24: 96-102, 2003.

27. Krawczyk M and Emerson BM: p50-associated COX-2 extragenic RNA (PACER) activates COX-2 gene expression by occluding repressive NF- $\mathrm{KB}$ complexes. eLife 3: e01776, 2014.

28. Pearson MJ, Philp AM, Heward JA, Roux BT, Walsh DA, Davis ET, Lindsay MA and Jones SW: Long intergenic noncoding RNAs mediate the human chondrocyte inflammatory response and are differentially expressed in osteoarthritis cartilage. Arthritis Rheumatol 68: 845-856, 2016.

29. Hu G, Gong A-Y, Wang Y, Ma S, Chen X, Chen J, Su CJ, Shibata A, Strauss-Soukup JK, Drescher KM, et al: LincRNA-Cox2 promotes late inflammatory gene transcription in macrophages through modulating SWI/SNF-mediated chromatin remodeling. J Immunol 196: 2799-2808, 2016.

30. Gutschner T, Hämmerle M and Diederichs S: MALAT1 - a paradigm for long noncoding RNA function in cancer. J Mol Med (Berl) 91: 791-801, 2013.

31. Özes AR, Miller DF, Özes ON, Fang F, Liu Y, Matei D, Huang T and Nephew KP: NF- $\kappa B$-HOTAIR axis links DNA damage response, chemoresistance and cellular senescence in ovarian cancer. Oncogene 35: 5350-5361, 2016.

32. Rajbhandari R, McFarland BC, Patel A, Gerigk M, Gray GK, Fehling SC, Bredel M, Berbari NF, Kim H, Marks MP, et al: Loss of tumor suppressive microRNA-31 enhances TRADD/NF- $\kappa \mathrm{B}$ signaling in glioblastoma. Oncotarget 6: 17805-17816, 2015

33. Xu Q, Deng F, Xing Z, Wu Z, Cen B, Xu S, Zhao Z, Nepomuceno R, Bhuiyan MI, Sun D, et al: Long non-coding RNA C2dat1 regulates CaMKII $\delta$ expression to promote neuronal survival through the NF- $\mathrm{KB}$ signaling pathway following cerebral ischemia. Cell Death Dis 7: e2173, 2016

34. IIott NE, Heward JA, Roux B, Tsitsiou E, Fenwick PS, Lenzi L, Goodhead I, Hertz-Fowler C, Heger A, Hall N, et al: Long non-coding RNAs and enhancer RNAs regulate the lipopolysaccharide-induced inflammatory response in human monocytes. Nat Commun 5: 3979, 2014.

35. Chan J, Atianand M, Jiang Z, Carpenter S, Aiello D, Elling R, Fitzgerald KA and Caffrey DR: Cutting edge: A natural antisense transcript, AS-IL1 $\alpha$, controls inducible transcription of the proinflammatory cytokine IL-1 $\alpha$. J Immunol 195: 1359-1363, 2015.

36. Zhou X, Han X, Wittfeldt A, Sun J, Liu C, Wang X, Gan LM, Cao $\mathrm{H}$ and Liang Z: Long non-coding RNA ANRIL regulates inflammatory responses as a novel component of NF- $\kappa B$ pathway. RNA Biol 13: 98-108, 2016

37. Li Z, Chao TC, Chang KY, Lin N, Patil VS, Shimizu C, Head SR, Burns JC and Rana TM: The long noncoding RNA THRIL regulates TNF $\alpha$ expression through its interaction with hnRNPL. Proc Natl Acad Sci USA 111: 1002-1007, 2014.

38. Cui H, Xie N, Tan Z, Banerjee S, Thannickal VJ, Abraham E and Liu G: The human long noncoding RNA lnc-IL7R regulates the inflammatory response. Eur J Immunol 44: 2085-2095, 2014. 
39. Nusse R and Varmus HE: Many tumors induced by the mouse mammary tumor virus contain a provirus integrated in the same region of the host genome. Cell 31: 99-109, 1982

40. Miki T, Yasuda SY and Kahn M: Wnt/ $\beta$-catenin signaling in embryonic stem cell self-renewal and somatic cell reprogramming. Stem Cell Rev 7: 836-846, 2011.

41. Serio RN: Wnt of the two horizons: Putting stem cell self-renewal and cell fate determination into context. Stem Cells Dev 23: 1975-1990, 2014

42. Ma Y, Yang Y, Wang F, Moyer MP, Wei Q, Zhang P, Yang Z, Liu W, Zhang $\mathrm{H}$, Chen $\mathrm{N}$, et al: Long non-coding RNA CCAL regulates colorectal cancer progression by activating $\mathrm{Wnt} / \beta$-catenin signalling pathway via suppression of activator protein $2 \alpha$. Gut 65: 1494-1504, 2015.

43. Fan Y, Shen B, Tan M, Mu X, Qin Y, Zhang F and Liu Y: Long non-coding RNA UCA1 increases chemoresistance of bladder cancer cells by regulating Wnt signaling. FEBS J 281: 1750-1758, 2014.

44. Cai Y, He J and Zhang D: Long noncoding RNA CCAT2 promotes breast tumor growth by regulating the Wnt signaling pathway. Onco Targets Ther 8: 2657-2664, 2015.

45. Xiao Z, Qu Z, Chen Z, Fang Z, Zhou K, Huang Z, Guo X and Zhang Y: LncRNA HOTAIR is a prognostic biomarker for the proliferation and chemoresistance of colorectal cancer via MiR-203a-3p-mediated Wnt/ $\beta$-catenin signaling pathway. Cell Physiol Biochem 46: 1275-1285, 2018.

46. Shao K, Shi T, Yang Y, Wang X, Xu D and Zhou P: Highly expressed lncRNA CRNDE promotes cell proliferation through Wnt/ $\beta$-catenin signaling in renal cell carcinoma. Tumour Biol 37 15997-16004, 2016.

47. Wang Y, He L, Du Y, Zhu P, Huang G, Luo J, Yan X, Ye B, Li C, $\mathrm{Xia}$ P, et al: The long noncoding RNA lncTCF7 promotes selfrenewal of human liver cancer stem cells through activation of Wnt signaling. Cell Stem Cell 16: 413-425, 2015.

48. Fu X, Li H, Liu C, Hu B, Li T and Wang Y: Long noncoding RNA AK126698 inhibits proliferation and migration of non-small cell lung cancer cells by targeting Frizzled-8 and suppressing Wnt/ $\beta$ catenin signaling pathway. OncoTargets Ther 9: 3815-3827, 2016.

49. Yuan Z, Yu X, Ni B, Chen D, Yang Z, Huang J, Wang J, Chen D and Wang L: Overexpression of long non-coding RNA-CTD903 inhibits colorectal cancer invasion and migration by repressing $\mathrm{Wnt} / \beta$-catenin signaling and predicts favorable prognosis. Int J Oncol 48: 2675-2685, 2016

50. Xia Y, He Z, Liu B, Wang P and Chen Y: Downregulation of Meg3 enhances cisplatin resistance of lung cancer cells through activation of the WNT/ $\beta$-catenin signaling pathway. Mol Med Rep 12: 4530-4537, 2015.

51. Li Z, Zhao L and Wang Q: Overexpression of long non-coding RNA HOTTIP increases chemoresistance of osteosarcoma cel by activating the Wnt $/ \beta$-catenin pathway. Am J Transl Res 8: 2385-2393, 2016

52. High FA and Epstein JA: The multifaceted role of Notch in cardiac development and disease. Nat Rev Genet 9: 49-61, 2008.

53. Wang Y, Wu P, Lin R, Rong L, Xue Y and Fang Y: LncRNA NALT interaction with NOTCH1 promoted cell proliferation in pediatric T cell acute lymphoblastic leukemia. Sci Rep 5: 13749 , 2015.

54. Zhou S, Yu L, Xiong M and Dai G: LncRNA SNHG12 promotes tumorigenesis and metastasis in osteosarcoma by upregulating Notch 2 by sponging miR-195-5p. Biochem Biophys Res Commun 495: 1822-1832, 2018.

55. Yang $X$, Duan $B$ and Zhou X: Long non-coding RNA FOXD2-AS1 functions as a tumor promoter in colorectal cancer by regulating EMT and Notch signaling pathway. Eur Rev Med Pharmacol Sci 21: 3586-3591, 2017.

56. Guo Q, Qian Z, Yan D, Li L and Huang L: LncRNA-MEG3 inhibits cell proliferation of endometrial carcinoma by repressing Notch signaling. Biomed Pharmacother 82: 589-594, 2016.

57. Katsushima K, Natsume A, Ohka F, Shinjo K, Hatanaka A, Ichimura N, Sato S, Takahashi S, Kimura H, Totoki Y, et al: Targeting the Notch-regulated non-coding RNA TUG1 for glioma treatment. Nat Commun 7: 13616, 2016.

58. Osaki M, Oshimura M and Ito H: PI3K-Akt pathway: Its functions and alterations in human cancer. Apoptosis 9: 667-676, 2004

59. Bellacosa A, Kumar CC, Di Cristofano A and Testa JR: Activation of AKT kinases in cancer: Implications for therapeutic targeting. Adv Cancer Res 94: 29-86, 2005.

60. Koirala P, Huang J, Ho TT, Wu F, Ding X and Mo YY: LncRNA AK023948 is a positive regulator of AKT. Nat Commun 8: $14422,2017$.
61. Cheng Z, Guo J, Chen L, Luo N, Yang W and Qu X: A long noncoding RNA AB073614 promotes tumorigenesis and predicts poor prognosis in ovarian cancer. Oncotarget 6: 25381-25389, 2015.

62. Hu L, Lv QL, Chen SH, Sun B, Qu Q, Cheng L, Guo Y, Zhou HH and Fan L: Up-regulation of long non-coding RNA AB073614 predicts a poor prognosis in patients with glioma. Int J Environ Res Public Health 13: 433, 2016.

63. Li J, Wang YM and Song YL: Knockdown of long noncoding RNA AB073614 inhibits glioma cell proliferation and migration via affecting epithelial-mesenchymal transition. Eur Rev Med Pharmacol Sci 20: 3997-4002, 2016.

64. Wang Y, Kuang H, Xue J, Liao L, Yin F and Zhou X: LncRNA AB073614 regulates proliferation and metastasis of colorectal cancer cells via the PI3K/AKT signaling pathway. Biomed Pharmacother 93: 1230-1237, 2017.

65. Song W, Mei JZ and Zhang M: lncRNA PlncRNA-1 promotes colorectal cancer cell progression by regulating PI3K/Akt signaling pathway. Oncol Res 26: 261-268, 2018.

66. Peng W, Wang Z and Fan H: IncRNA NEAT1 impacts cell proliferation and apoptosis of colorectal cancer via regulation of Akt signaling. Pathol Oncol Res 23: 651-656, 2017.

67. Li C, Liang G, Yang S, Sui J, Yao W, Shen X, Zhang Y, Peng H, Hong W, Xu S, et al: Dysregulated lncRNA-UCA1 contributes to the progression of gastric cancer through regulation of the PI3K-Akt-mTOR signaling pathway. Oncotarget 8: 9347693491, 2017.

68. Xu S, Sui S, Zhang J, Bai N, Shi Q, Zhang G, Gao S, You Z, Zhan C, Liu F, et al: Downregulation of long noncoding RNA MALAT1 induces epithelial-to-mesenchymal transition via the PI3K-AKT pathway in breast cancer. Int J Clin Exp Pathol 8: 4881-4891, 2015.

69. Jin Y, Feng SJ, Qiu S, Shao N and Zheng JH: LncRNA MALAT1 promotes proliferation and metastasis in epithelial ovarian cancer via the PI3K-AKT pathway. Eur Rev Med Pharmacol Sci 21: 3176-3184, 2017.

70. Yang W, Li X, Qi S, Li X, Zhou K, Qing S, Zhang Y and Gao MQ: lncRNA H19 is involved in TGF- $\beta 1$-induced epithelial to mesenchymal transition in bovine epithelial cells through PI3K/AKT Signaling Pathway. PeerJ 5: e3950, 2017.

71. Wang P, Chen D, Ma H and Li Y: LncRNA SNHG12 contributes to multidrug resistance through activating the MAPK/Slug pathway by sponging miR-181a in non-small cell lung cancer. Oncotarget 8: 84086-84101, 2017.

72. Kong Q, Zhang S, Liang C, Zhang Y, Kong Q, Chen S, Qin J and Jin Y: lncRNA XIST functions as a molecular sponge of miR-194-5p to regulate MAPK1 expression in hepatocellular carcinoma cell. J Cell Biochem 119: 4458-4468, 2018.

73. Wu XS, Wang XA, Wu WG, Hu YP, Li ML, Ding Q, Weng H, Shu YJ, Liu TY, Jiang L, et al: MALAT1 promotes the proliferation and metastasis of gallbladder cancer cells by activating the ERK/MAPK pathway. Cancer Biol Ther 15: 806-814, 2014

74. Chen H, Wang X, Yan X, Cheng X, He X and Zheng W: LncRNA MALAT1 regulates sepsis-induced cardiac inflammation and dysfunction via interaction with miR-125b and p38 MAPK/NFאB. Int Immunopharmacol 55: 69-76, 2018.

75. Chen L, Feng P, Zhu X, He S, Duan J and Zhou D: Long non-coding RNA Malat1 promotes neurite outgrowth through activation of ERK/MAPK signalling pathway in N2a cells. J Cell Mol Med 20: 2102-2110, 2016.

76. Jiang W, Zhang D, Xu B, Wu Z, Liu S, Zhang L, Tian Y, Han X and Tian D: Long non-coding RNA BANCR promotes proliferation and migration of lung carcinoma via MAPK pathways. Biomed Pharmacother 69: 90-95, 2015.

77. Li R, Zhang L, Jia L, Duan Y, Li Y, Bao L and Sha N: Long non-coding RNA BANCR promotes proliferation in malignant melanoma by regulating MAPK pathway activation. PLoS One 9: e100893, 2014.

78. Rosenbloom KR, Dreszer TR, Long JC, Malladi VS, Sloan CA, Raney BJ, Cline MS, Karolchik D, Barber GP, Clawson H, et al: ENCODE whole-genome data in the UCSC Genome Browser: Update 2012. Nucleic Acids Res 40: D912-D917, 2012.

79. Schorderet P and Duboule D: Structural and functional differences in the long non-coding RNA hotair in mouse and human. PLoS Genet 7: e1002071, 2011.

80. Brown CJ, Ballabio A, Rupert JL, Lafreniere RG, Grompe M, Tonlorenzi R and Willard HF: A gene from the region of the human $\mathrm{X}$ inactivation centre is expressed exclusively from the inactive X chromosome. Nature 349: 38-44, 1991. 
81. Brown CJ, Hendrich BD, Rupert JL, Lafrenière RG, Xing Y, Lawrence J and Willard HF: The human XIST gene: Analysis of a $17 \mathrm{~kb}$ inactive X-specific RNA that contains conserved repeats and is highly localized within the nucleus. Cell 71: 527-542, 1992.

82. Engreitz JM, Pandya-Jones A, McDonel P, Shishkin A, Sirokman K, Surka C, Kadri S, Xing J, Goren A, Lander ES, et al: The Xist lncRNA exploits three-dimensional genome architecture to spread across the X chromosome. Science 341 1237973, 2013

83.Zhao J, Sun BK, Erwin JA, Song J-J and Lee JT: Polycomb proteins targeted by a short repeat RNA to the mouse X chromosome. Science 322: 750-756, 2008.

84. Chen CK, Blanco M, Jackson C, Aznauryan E, Ollikainen N, Surka C, Chow A, Cerase A, McDonel P and Guttman M: Xist recruits the $\mathrm{X}$ chromosome to the nuclear lamina to enable chromosome-wide silencing. Science 354: 468-472, 2016.

85. Wang CY, Froberg JE, Blum R, Jeon Y and Lee JT: Comment on 'Xist recruits the $\mathrm{X}$ chromosome to the nuclear lamina to enable chromosome-wide silencing'. Science 356: 356, 2017

86. Chen CK, Chow A, Lai M and Guttman M: Response to Comment on 'Xist recruits the $\mathrm{X}$ chromosome to the nuclear lamina to enable chromosome-wide silencing'. Science 356: 5439, 2017.

87. Suemori H and Noguchi S: Hox C cluster genes are dispensable for overall body plan of mouse embryonic development. Dev Biol 220: 333-342, 2000.

88. Amândio AR, Necsulea A, Joye E, Mascrez B and Duboule D: Hotair is dispensible for mouse development. PLoS Genet 12 e1006232, 2016

89.Lai KM, Gong G, Atanasio A, Rojas J, Quispe J, Posca J, White D, Huang M, Fedorova D, Grant C, et al: Diverse phenotypes and specific transcription patterns in twenty mouse lines with ablated LincRNAs. PLoS One 10: e0125522, 2015.

90. Tano K, Onoguchi-Mizutani R, Yeasmin F, Uchiumi F, Suzuki Y, Yada T and Akimitsu N: Identification of Minimal p53 Promoter Region Regulated by MALAT1 in Human Lung Adenocarcinoma Cells. Front Genet 8: 208, 2018.

91. Yang P, Yang Y, An W, Xu J, Zhang G, Jie J and Zhang Q: The long noncoding RNA-ROR promotes the resistance of radiotherapy for human colorectal cancer cells by targeting the p53/miR-145 pathway. J Gastroenterol Hepatol 32: 837-845, 2017

92. Chen RP, Huang ZL, Liu LX, Xiang MQ, Li GP, Feng JL, Liu B and $\mathrm{Wu}$ LF: Involvement of endoplasmic reticulum stress and p53 in lncRNA MEG3-induced human hepatoma HepG2 cell apoptosis. Oncol Rep 36: 1649-1657, 2016.

93. Li J, Bian EB, He XJ, Ma CC, Zong G, Wang HL and Zhao B Epigenetic repression of long non-coding RNA MEG3 mediated by DNMT1 represses the 553 pathway in gliomas. Int J Oncol 48: 723-733, 2016

94.Lu KH, Li W, Liu XH, Sun M, Zhang ML, Wu WQ, Xie WP and Hou YY: Long non-coding RNA MEG3 inhibits NSCLC cells proliferation and induces apoptosis by affecting p53 expression. BMC Cancer 13: 461, 2013.

95.Zhu J, Liu S, Ye F, Shen Y, Tie Y, Zhu J, Wei L, Jin Y, Fu H, $\mathrm{Wu} \mathrm{Y}$, et al: Long noncoding RNA MEG3 interacts with p53 protein and regulates partial p53 target genes in hepatoma cells. PLoS One 10: e0139790, 2015.

96. Sun L, Li Y and Yang B: Downregulated long non-coding RNA MEG3 in breast cancer regulates proliferation, migration and invasion by depending on $\mathrm{p} 53$ 's transcriptional activity. Biochem Biophys Res Commun 478: 323-329, 2016.

97.Zhang EB, Yin DD, Sun M, Kong R, Liu XH, You LH, Han L, Xia R, Wang KM, Yang JS, et al: P53-regulated long non-coding RNA TUG1 affects cell proliferation in human non-small cell lung cancer, partly through epigenetically regulating HOXB7 expression. Cell Death Dis 5: e1243, 2014.

98. Huang J, Zhou N, Watabe K, Lu Z, Wu F, Xu M and Mo YY: Long non-coding RNA UCA1 promotes breast tumor growth by suppression of p27 (Kip1). Cell Death Dis 5: e1008, 2014.

99.Zhai N, Xia Y, Yin R, Liu J and Gao F: A negative regulation loop of long noncoding RNA HOTAIR and p53 in non-smallcell lung cancer. OncoTargets Ther 9: 5713-5720, 2016.

100. Su P, Wang F, Qi B, Wang T and Zhang S: p53 regulationassociation long non-coding RNA (LncRNA PRAL) inhibits cell proliferation by regulation of P53 in human lung cancer. Med Sci Monit 23: 1751-1758, 2017

101. Gong Z, Zhang S, Zeng Z, Wu H, Yang Q, Xiong F, Shi L, Yang J, Zhang W, Zhou Y, et al: LOC401317, a p53-regulated long non-coding RNA, inhibits cell proliferation and induces apoptosis in the nasopharyngeal carcinoma cell line HNE2. PLoS One 9: e110674, 2014.
102.Zhai W, Li X, Wu S, Zhang Y, Pang H and Chen W: Microarray expression profile of $\operatorname{lncRNAs}$ and the upregulated ASLNC04080 lncRNA in human endometrial carcinoma. Int J Oncol 46: 2125-2137, 2015

103. Thorenoor N, Faltejskova-Vychytilova P, Hombach S, Mlcochova J, Kretz M, Svoboda M and Slaby O: Long noncoding RNA ZFAS1 interacts with CDK1 and is involved in p53-dependent cell cycle control and apoptosis in colorectal cancer. Oncotarget 7: 622-637, 2016.

104. Li P, Zhang X, Wang L, Du L, Yang Y, Liu T, Li C and Wang C: lncRNA HOTAIR Contributes to 5FU Resistance through Suppressing miR-218 and Activating NF- $\kappa$ B/TS Signaling in Colorectal Cancer. Mol Ther Nucleic Acids 8: 356-369, 2017.

105. Liao Z, Zhao J and Yang Y: Downregulation of lncRNA H19 inhibits the migration and invasion of melanoma cells by inactivating the $\mathrm{NF} \kappa \mathrm{B}$ and PI3K/Akt signaling pathways. Mol Med Rep 17: 7313-7318, 2018

106. Yang T, Li S, Liu J, Yin D, Yang X and Tang Q: IncRNA-NKILA/ NF- $\mathrm{KB}$ feedback loop modulates laryngeal cancer cell proliferation, invasion, and radioresistance. Cancer Med 7: 2048-2063, 2018.

107. Bian D, Gao C, Bao K and Song G: The long non-coding RNA NKILA inhibits the invasion-metastasis cascade of malignant melanoma via the regulation of NF-kB. Am J Cancer Res 7: $28-40,2017$

108. Huang W, Cui X, Chen J, Feng Y, Song E, Li J and Liu Y: Long non-coding RNA NKILA inhibits migration and invasion of tongue squamous cell carcinoma cells via suppressing epithelialmesenchymal transition. Oncotarget 7: 62520-62532, 2016.

109. Ma Y, Zhou G, Li M, Hu D, Zhang L, Liu P and Lin K: Long noncoding RNA DANCR mediates cisplatin resistance in glioma cells via activating AXL/PI3K/Akt/NF- $\mathrm{kB}$ signaling pathway. Neurochem Int 118: 233-241, 2018.

110. Liang S, Zhang S, Wang P, Yang C, Shang C, Yang J and Wang J: LncRNA, TUG1 regulates the oral squamous cell carcinoma progression possibly via interacting with $\mathrm{Wnt} / \beta$-catenin signaling. Gene 608: 49-57, 2017.

111. Yang YT, Wang YF, Lai JY, Shen SY, Wang F, Kong J, Zhang W and Yang HY: Long non-coding RNA UCA1 contributes to the progression of oral squamous cell carcinoma by regulating the WNT/ $\beta$-catenin signaling pathway. Cancer Sci 107: 1581-1589, 2016.

112. Ge XS, Ma HJ, Zheng XH, Ruan HL, Liao XY, Xue WQ, Chen YB, Zhang Y and Jia WH: HOTAIR, a prognostic factor in esophageal squamous cell carcinoma, inhibits WIF-1 expression and activates Wnt pathway. Cancer Sci 104: 1675-1682, 2013

113. Wu KF, Liang WC, Feng L, Pang JX, Waye MM, Zhang JF and Fu WM: H19 mediates methotrexate resistance in colorectal cancer through activating Wnt/ $\beta$-catenin pathway. Exp Cell Res 350: 312-317, 2017

114. Cao Y, Shi H, Ren F, Jia Y and Zhang R: Long non-coding RNA CCAT1 promotes metastasis and poor prognosis in epithelial ovarian cancer. Exp Cell Res 359: 185-194, 2017.

115. Fu Z, Chen C, Zhou Q, Wang Y, Zhao Y, Zhao X, Li W, Zheng S, Ye H, Wang L, et al: LncRNA HOTTIP modulates cancer stem cell properties in human pancreatic cancer by regulating HOXA9. Cancer Lett 410: 68-81, 2017.

116. Yue B, Liu C, Sun H, Liu M, Song C, Cui R, Qiu S and Zhong M: A Positive Feed-Forward Loop between LncRNA-CYTOR and Wnt/ק-Catenin Signaling Promotes Metastasis of Colon Cancer. Mol Ther 26: 1287-1298, 2018.

117. Liu B, Pan CF, He ZC, Wang J, Wang PL, Ma T, Xia Y and Chen YJ: Long noncoding RNA-LET suppresses tumor growth and EMT in lung adenocarcinoma. Biomed Res Int 2016 4693471, 2016

118. Wang X, Lu X, Geng Z, Yang G and Shi Y: lncRNA PTCSC3/ miR-574-5p governs cell proliferation and migration of papillary thyroid carcinoma via Wnt $/ \beta$-catenin signaling. J Cell Biochem 118: 4745-4752, 2017.

119. Zhang Z, Zhou C, Chang Y, Zhang Z, Hu Y, Zhang F, Lu Y, Zheng L, Zhang W, Li X, et al: Long non-coding RNA CASC11 interacts with hnRNP-K and activates the WNT/ $\beta$-catenin pathway to promote growth and metastasis in colorectal cancer. Cancer Lett 376: 62-73, 2016.

120.Zhang F, Wan M, Xu Y, Li Z, Leng K, Kang P, Cui Y and Jiang $X$ : Long noncoding RNA PCAT1 regulates extrahepatic cholangiocarcinoma progression via the Wnt/ $\beta$-cateninsignaling pathway. Biomed Pharmacother 94: 55-62, 2017.

121. Wang Y, Zhou J, Xu YJ and Hu HB: Long non-coding RNA LINC00968 acts as oncogene in NSCLC by activating the Wnt signaling pathway. J Cell Physiol 233: 3397-3406, 2018. 
122.Hang Q, Sun R, Jiang C and Li Y: Notch 1 promotes cisplatinresistant gastric cancer formation by upregulating lncRNA AK022798 expression. Anticancer Drugs 26: 632-640, 2015.

123.Lu S, Dong W, Zhao P and Liu Z: lncRNA FAM83H-AS1 is associated with the prognosis of colorectal carcinoma and promotes cell proliferation by targeting the Notch signaling pathway. Oncol Lett 15: 1861-1868, 2018.

124. Chen H, Liu JZ, Hu GJ, Shi LL and Lan T: Promotion of proliferation and metastasis of hepatocellular carcinoma by LncRNA00673 based on the targeted-regulation of notch signaling pathway. Eur Rev Med Pharmacol Sci 21: 3412-3420, 2017.

125.Zhang L, Liang X and Li Y: Long non-coding RNA MEG3 inhibits cell growth of gliomas by targeting miR-93 and inactivating PI3K/AKT pathway. Oncol Rep 38: 2408-2416, 2017.

126.Li T, Xiao Y and Huang T: HIF-1 $\alpha$-induced upregulation of lncRNA UCA1 promotes cell growth in osteosarcoma by inactivating the PTEN/AKT signaling pathway. Oncol Rep 39: 1072-1080, 2018.

127. Yun-Bo F, Xiao-Po L, Xiao-Li L, Guo-Long C, Pei Z and Fa-Ming T: LncRNA TUG1 is upregulated and promotes cell proliferation in osteosarcoma. Open Med (Wars) 11: 163-167, 2016.

128. Yan J, Dang Y, Liu S, Zhang Y and Zhang G: LncRNA HOTAIR promotes cisplatin resistance in gastric cancer by targeting miR-126 to activate the PI3K/AKT/MRP1 genes. Tumour Biol 37: 16345-16355, 2016.

129. Wang H, Li Q, Tang S, Li M, Feng A, Qin L, Liu Z and Wang X: The role of long noncoding RNA HOTAIR in the acquired multidrug resistance to imatinib in chronic myeloid leukemia cells. Hematology 22: 208-216, 2017.

130. Jiang N, Wang X, Xie X, Liao Y, Liu N, Liu J, Miao N, Shen J and Peng T: lncRNA DANCR promotes tumor progression and cancer stemness features in osteosarcoma by upregulating AXL via miR-33a-5p inhibition. Cancer Lett 405: 46-55, 2017.

131. Yuan Q, Liu Y, Fan Y, Liu Z, Wang X, Jia M, Geng Z, Zhang J and Lu X: LncRNA HOTTIP promotes papillary thyroid carcinoma cell proliferation, invasion and migration by regulating miR-637. Int J Biochem Cell Biol 98: 1-9, 2018

132. Xue D, Zhou C, Lu H, Xu R, Xu X and He X: LncRNA GAS5 inhibits proliferation and progression of prostate cancer by targeting miR-103 through AKT/mTOR signaling pathway. Tumour Biol 37: 16187-16197, 2016.

133. Huang YS, Chang CC, Lee SS, Jou YS and Shih HM: Xist reduction in breast cancer upregulates $\mathrm{AKT}$ phosphorylation via HDAC3-mediated repression of PHLPP1 expression. Oncotarget 7: 43256-43266, 2016.

134.Lu Y, Li Y, Chai X, Kang Q, Zhao P, Xiong J and Wang J: Long noncoding RNA HULC promotes cell proliferation by regulating PI3K/AKT signaling pathway in chronic myeloid leukemia. Gene 607: 41-46, 2017.

135. Wang J, Ma W and Liu Y: Long non-coding RNA HULC promotes bladder cancer cells proliferation but inhibits apoptosis via regulation of ZIC2 and PI3K/AKT signaling pathway. Cancer Biomark 20: 425-434, 2017.
136. He XS, Guo LC, Du MZ, Huang S, Huang RP, Zhan SH, Gu DM, Liu WS, Wang XM, Wu $\mathrm{H}$, et al: The long non-coding RNA NONHSAT062994 inhibits colorectal cancer by inactivating Akt signaling. Oncotarget 8: 68696-68706, 2017.

137. Han W and Liu J: LncRNA-p21 inhibited the proliferation of osteosarcoma cells via the miR-130b/PTEN/AKT signaling pathway. Biomed Pharmacother 97: 911-918, 2018

138. Wang L, Wang F, Na L, Yu J, Huang L, Meng ZQ, ChenZ, ChenH, Ming LL and Hua YQ: LncRNA AB209630 inhibits gemcitabine resistance cell proliferation by regulating PI3K/ AKT signaling in pancreatic ductal adenocarcinoma. Cancer Biomark 22: 169-174, 2018

139. Wang B, Jiang H, Wang L, Chen X, Wu K, Zhang S, Ma S and Xia B: Increased MIR31HG lncRNA expression increases gefitinib resistance in non-small cell lung cancer cell lines through the EGFR/PI3K/AKT signaling pathway. Oncol Lett 13: 3494-3500, 2017.

140. Chen S, Wang Y, Zhang JH, Xia QJ, Sun Q, Li ZK, Zhang JG, Tang MS and Dong MS: Long non-coding RNA PTENP1 inhibits proliferation and migration of breast cancer cells via AKT and MAPK signaling pathways. Oncol Lett 14: 4659-4662, 2017

141. Li Q, Feng Y, Chao X, Shi S, Liang M, Qiao Y, Wang B, Wang P and Zhu Z: HOTAIR contributes to cell proliferation and metastasis of cervical cancer via targetting miR-23b/MAPK1 axis. Biosci Rep 38: BSR20171563, 2018.

142. Gao R, Zhang R, Zhang C, Zhao L and Zhang Y: Long noncoding RNA CCAT1 promotes cell proliferation and metastasis in human medulloblastoma via MAPK pathway. Tumori 104: 43-50, 2017.

143. Liu S, Yan G, Zhang J and Yu L: Knockdown of long noncoding RNA (lncRNA) metastasis-associated lung adenocarcinoma transcript 1 (MALAT1) inhibits proliferation, migration, and invasion and promoted apoptosis by targeting miR-124 in retinoblastoma. Oncol Res: May 21, 2017 (Epub ahead of print). doi: 10.3727/096504017X14953948675403

144. Huang JL, Ren TY, Cao SW, Zheng SH, Hu XM, Hu YW, Lin L, Chen J, Zheng L and Wang Q: HBx-related long noncoding RNA DBH-AS1 promotes cell proliferation and survival by activating MAPK signaling in hepatocellular carcinoma. Oncotarget 6: 33791-33804, 2015.

145. Peng WX, Huang JG, Yang L, Gong AH and Mo YY: Linc-RoR promotes MAPK/ERK signaling and confers estrogen-independent growth of breast cancer. Mol Cancer 16: 161, 2017.

146. Wu F, Mo Q, Wan X, Dan J and Hu H: NEAT1/has-mir-98-5p/ MAPK6 axis is involved in non-small-cell lung cancer (NSCLC) development. J Cell Biochem: Nov 2, 2017 (Epub ahead of print). doi: $10.1002 /$ jcb. 26442

147. Peng $\mathrm{W}$ and Fan H: Long noncoding RNA CCHE1 indicates a poor prognosis of hepatocellular carcinoma and promotes carcinogenesis via activation of the ERK/MAPK pathway. Biomed Pharmacother 83: 450-455, 2016. 